\title{
Analisis Kebutuhan Pelatihan Kewirausahaan: Sebuah Upaya Pengembangan Kemandirian Ekonomi bagi Penyandang Disabilitas
}

\section{Self-Employment Training Needs Analysis: An Effort to Develop Economic Independence for Disabilities}

\author{
Imas Diana Aprilia ${ }^{1}$, Johar Permana ${ }^{2}$, dan Liah Siti Syarifah ${ }^{3}$ \\ ${ }^{1,2}$ Universitas Pendidikan Indonesia (UPI) Bandung, Jawa Barat, Indonesia \\ ${ }^{3}$ STAI Syamsul 'Ulum Sukabumi, Jawa Barat, Indonesia \\ imasdiana@upi.edu,permanajohar@upi.edu, liahss@staisyamsululum.ac.id
}

Naskah diterima tanggal 02/06/2019, direvisi akhir tanggal 00/00/2019, disetujui tanggal 11/12/2019

\begin{abstract}
Abstrak
Melalui Undang-Undang Nomor 8 Tahun 2016 pemerintah berupaya mengakomodasi pemenuhan hak penyandang disabilitas di antaranya dalam hal pekerjaan. Dari hasil survey, wirausaha menjadi pilihanbidang usahabagi sebagian besar responden dari penyandang disabilitas yang sudah bekerja maupun belum bekerja. Mengingat akan transisi kebutuhan penyandang disabilitas saat dewasa, dengan akses pendidikan dan pekerjaan yang masih sangat terbatas, penelitian ini ditujukan untuk menganalisis kebutuhan pelatihan kewirausahaan bagi penyandang disabilitas. Penelitian menggunakan pendekatan kualitati-kuantitatif dengan metode deskriptif ex-post-facto. Populasi terdiri dari anggota Persatuan Penyandang Disabilitas Indonesia (PPDI) Kabupaten Subang dan sampel penelitian diambil dengan metode purposive sampling yaitu anggota Persatuan Penyandang Disabilitas Indonesia (PPDI) Kabupaten Subang pada usia kerja (15-64 tahun). Data penelitian didapat melalui angket yang dibagikan kepada responden, wawancara dengan ketua Persatuan Penyandang Disabilitas Indonesia (PPDI) Kabupaten Subang dan wawancara langsung dengan beberapa responden, serta beberapa dokumen yang relevan. Kemudian data dianalisis secara induktif, dan untuk membantu mendapatkan keakurasian kebutuhan pelatihan digunakan skema proses atau langkah analisis kebutuhan dari Kementerian Sosial Republik Indonesia. Hasil penelitian menunjukkan bahwa bidang dan jenis pelatihan yang dibutuhkan responden adalah keilmuan dasar wirausaha dan pemasaran digital (digital marketing). Dari penelitian tersebut dapat disimpulkan bahwa kemandirian penyandang disabilitas bisa diupayakan dengan pengembangan karir di antaranya melalui kegiatan pelatihan dalampembekalansoft skill dan hard skillyang dibutuhkan.Kegiatan ini diharapkan dapat mengakomodir penyandang disabilitas baik yang baru mulai bisnis atau sedang mengembangkannya.
\end{abstract}

Kata Kunci: Digital Marketing, Disabilitas, Kemandirian Ekonomi, Wirausaha

\begin{abstract}
Based on Law No. 8 of 2016, the government attempted to accommodate the compliance of the rights of disabilities, including work. Self-employment is the choice of business for most respondents from disabilities who are working or not working. By considering the transition needs of disabilities as adults, with access to education and employment was limited, this research is intended to analyze the need for self-employment training for disabilities. The analysis uses qualitative and quantitative approaches with ex post facto research design. The population consists of members of the Indonesian Disability Association (PPDI) Subang, and the sample was taken by a purposive sampling method, namely members of the Indonesian Disability Association (PPDI) Subang Regency at the working-age (15-64 years). The research data was obtained through a questionnaire distributed to respondents, interviews with the principal of the Indonesian Disability Association (PPDI) Subang and direct interviews with several respondents, and several relevant documents. Then, the data is analyzed inductively, and to help
\end{abstract}


get the accuracy of the training needs a process scheme or needs analysis step from the Ministry of the Social Republic of Indonesia. Based on research, it was found that the fields and types of training required by respondents were concerning essential entrepreneurship and digital marketing. From this research, it can be concluded that the economic independence of disabilities can be pursued with career development, including training to develop the soft skills and hard skills needed. This training expected to accommodate disabilities, whether they are just starting a business or are growing it.

Keywords: Digital Marketing, Disabilities, Economic Independence, Self-Employment

\section{PENDAHULUAN}

Kepercayaan terhadap kemampuan diri untuk menyelesaikan persoalan tanpa bantuan khusus orang lain, keenggana untuk dikontrol orang lain, mampu melakukan kegiatan dan menyelesaikan sendiri masalah yang dihadapi merupakan bagian dari konsep kemandirian yang disampaikan Aprilia (2009). Konsep kemandirian tersebut menjadi dasar pijakan akan penelitian ini yang lebih spesifiknya fokus pada masalah kemandirian ekonomi yang diasumsikan dapat jadi salah satu solusi untuk kesejahteraan masyarakat (Novalina \& Rusiadi, 2018)tidak terkecuali bagi penyandang disabilitas melalui pengoptimalan potensi yang dimiliki (Wasita, 2019).Tehrani (2004) menjelaskan bahwa mandiri secaraekonomi yaitu masyarakat dapat memenuhi kebutuhan pribadi dalam batas mensejahterakan (diri), tidak membutuhkan dan tidak bergantung pada orang lain dalam menjalankan persoalan ekonomi.

Kemandirian ekonomi biasanya diupayakan dengan bekerja. Bagi penyandang disabilitas, pemerintah telah menjamin akses yang setara terhadap manfaat dan program dalam sistem jaminan sosial nasional di bidang ketenagakerjaan yaitu Pemerintah, Pemerintah Daerah, Badan Usaha Milik Negara, dan Badan Usaha Milik Daerah wajib mempekerjakan paling sedikit 2\% (dua persen) penyandang disabilitas dari jumlah pegawai atau pekerja, sedangkan perusahaan swasta wajib mempekerjakan paling sedikit $1 \%$ (satu persen) penyandang disabilitas dari jumlah pegawai atau pekerja (Undang-Undang no 8 Tahun 2016). Hal tersebut merefleksikan telah meningkatnya upaya untuk memerangi pengucilan serta tidak diberikannya peluang yang setara kepada penyandang disabilitas (International Labour Organization, 2013).

Namun nyatanyasampai saat ini pelibatan kaum penyandang disabilitas sebagai karyawan di perusahaan atau pegawai di instansi pemerintah dinilai masih minim (Triyudha, 2018). Ketiadaan kerjasama antar institusi diperkirakan menjadi salah satu penyebabnya, padahal pemenuhan hak ketenagakerjaan bagi penyandang disabilitas hanya bisa dilakukan jika kerjasama antara pemerintah dengan masyarakat dan dunia usaha/ industri dilakukan secara terorganisisr dan sinergis (Permanaet al., 2019, misalnya melalui kegiatan magang (Permana \& Syarifah, 2018). Belum lagi, kasus-kasus seperti pemberian upah yang rendah (Myklebust \& Finn Ove, 2005), penempatan dalam pekerjaan yang tidak terampil (Schriner, 2001) menjadideretanmasalahyangdihadapipenyandang disabilitas di dunia kerja. Menurut Koordinator Wilayah Asosiasi Pengusaha Indonesia (Apindo) Surabaya bahwa minimnya serapan pekerja dari kelompok penyandang disabilitas diidentifikasi karena cost untuk mempekerjakan penyandang disabilitas dianggap tinggi (Kustiani, 2019).

Pada dasarnya ada banyak cara dalam mengupayakan kemandirian ekonomi bagi penyandang disabilitas. Meskipun sebuah studi menunjukkan bahwa peluang untuk mencapai kemandirian ekonomi lebih tinggi untuk pria daripada wanita; lebih tinggi untuk wanita muda tanpa anak daripada mereka yang memiliki anak; dan lebih baik bagi mereka yang memiliki kemampuan fungsional tinggi dibandingkan dengan mereka yang memiliki tingkat fungsional lebih rendah (Myklebust \& Finn Ove, 2005), namun hal yang paling fundamental dalam masalah kemandirian ini adalah keterampilan (skill) yang dimiliki masyarakat disabilitas. Dengan terbatasnya lowongan pekerjaan, bukan hal mustahil lagi bagi penyang disabilitas yang memiliki skill bisa mandiri secara ekonomi, misalnya dengan berwirausaha.

Lebih lanjut, masalah keterampilan di atas menggarisbawahi perlunya pengembangan skill 
bagi penyandang disabilitas di antaranya melalui pelatihan. Kegiatan pelatihan diarahkan pada realisasi keterampilan yang dibutuhkandunia kerja (Baker-Ericzen et al., 2009), sehingga dapat memfasilitasi proses integrasi mereka ke dalam dunia kerja.Bagi yang sudah bekerja, pelatihan katerampilan ini juga menjadi upaya pengembangan karir mereka yang melibatkan pengetahuan diri tentang kepribadian, minat, keterampilan, dan kemampuan (Kerka, 2002).

Sebelum dilakukan pelatihan, dilakukan analisis kebutuhan pelatihan untuk memastikan bahwa para partisipan yang mengikuti pelatihan adalah orang yang tepat. Sisi pentingnya juga adalah untuk mengidentifikasi bahwa jenis pelatihan serta metodenya sesuai dengan sesuai dengan tema pelatihan. Maka dari itu, penelitian ini bertujuan untuk menganalisis kebutuhan pelatihan bagi penyandang disabilitas baik yang belum maupun sudah bekerja sebagai upaya pengembangan skill dan karir mereka untuk kemandirian ekonomi di masa depan.

\section{METODE PENELITIAN}

Penelitian ini menggunakan metode ex-post-facto yang merupakan penelitian di mana variabel-variabel (penelitian) telah terjadi ketika peneliti mulai melakukan penelitian (Kerlinger, 1964) dantidak ada kontrol terhadap variabel (Natsir, 1999).

Populasi penelitian terdiri dari penyandang disabilitas Kabupaten Subang yang dalam hal ini dilakukan melalui Persatuan Penyandang Disabilitas Indonesia (PPDI) Kabupaten Subang. Untukmenunjang keabsahan penelitian, ditetapkan kriteria tertentu dalam pengambilan sampel penelitiannya (purposive sampling) yaitu anggota Persatuan Penyandang Disabilitas Indonesia (PPDI) Kabupaten Subang pada usia kerja (15-64 tahun).

Data penelitian didapatkan melalui angket yang dibagikan kepada anggota Persatuan Penyandang Disabilitas Indonesia (PPDI) Kabupaten Subang kategori usia kerja, wawancara dengan ketua Persatuan Penyandang Disabilitas Indonesia (PPDI) Kabupaten Subang dan wawancara langsung dengan beberapa anggotanya, sedangkan data sekunder diambil dari beberapa dokumen yang relevan.

Kemudian data diolah dan dianalisis secara induktif dengan skema proses atau langkah analisis kebutuhan pelatihan dari Kementerian Sosial Republik Indonesia yaitu sebagai berikut (Kementerian Sosial Republik Indonesia, 2012):

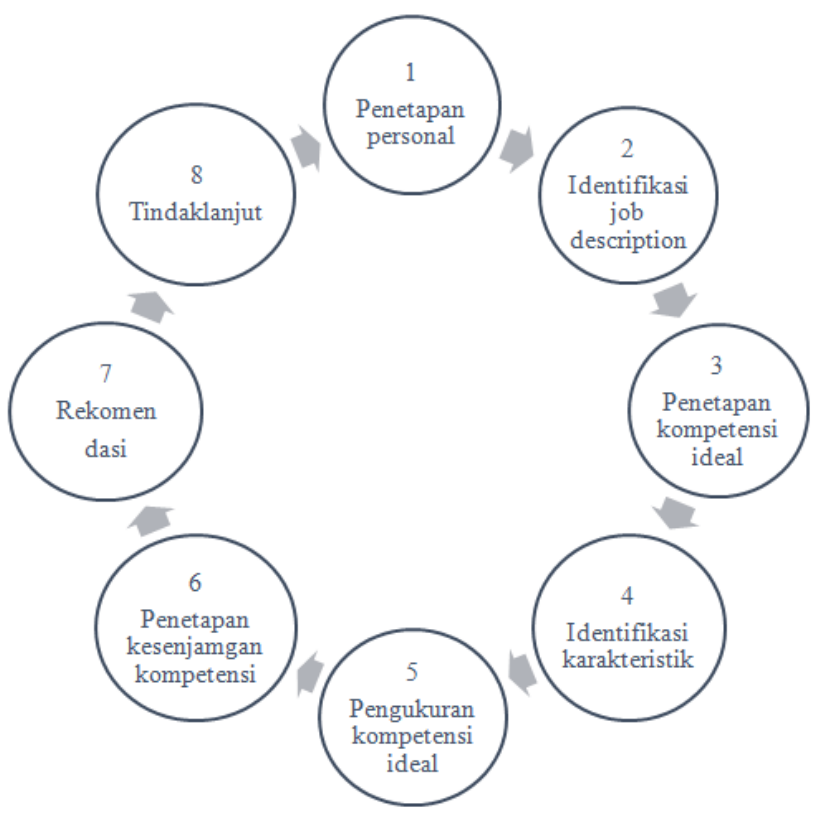

Gambar 1 langkah analisis kebutuhan pelatihan

Berdasarkan gambar 1 yaitu analisis kebutuhan pelatihan untuk penyandang disabilitas dilakukan dengan tahapan berikut:
1. Penetapan personal yang akan diassessmen dijelaskan berdasarkan identitas dasar dan jumlahnya 
2. Identifikasi job description melalui tugas dan fungsi pekerjaan

3. Penetapan kompetensi ideal untuk dapat melaksanakan tugas dan fungsi pekerjaan

4. Identifikasi karakteristik peserta melalui ciri-ciri yang diperoleh karena kelahiran dan interaksi dengan lingkungan sosial.

5. Pengukuran kompetensi aktual peserta dengan menggunakan instrumen wawancara, angket dan sebagainya

6. Penetapan kesenjangan kompetensi yaitu perbandingan antara kompetensi ideal dengan kompetensi faktual.

7. Rekomendasi pelatihan yang menjelas tentang jenis kebutuhan pelatihan dan materi pelatihan.

8. Tindaklanjut merupakan pembuatan desain pelatihan untuk memenuhi kebutuhan peserta pelatihan.

Dengan pendekatan penelitian dan metodenya, jenis data dan innstrumen pengumpulan datanya, teknik analisis data serta langkah-langkah analisis kebutuhan pelatihan yang telah dipaparkan di atas, penelitian ini diharapkan dapat menganalisis kebutuhan pelatihan yang dibutuhkan oleh penyandang disabilitas yang dalam hal ini dilakukan melalui Persatuan Penyandang Disabilitas (PPDI) Kabupaten Subang.

\section{HASIL DAN PEMBAHASAN}

Penelitian ini bertujuan untuk menganalisis kebutuhan pelatihan pada penduduk disabilitas usia kerja di Kabupaten Subang. Menurut Kementerian Sosial Republik Indonesia (2012), proses atau langkah analisis kebutuhan pelatihan dilakukan melaui penetapan personel, identifikasi job description, penetapan kompetensi ideal, identifikasi karakteristik, pengukuran kompetensi aktual, penetapan kesenjangan kompetensi, rekomendasi dan tindaklanjut. Untuk lebihjelasnyaakan diuraikan dengan penjelasan sebagai berikut:

\section{Penetapan Personel}

Analisis kebutuhan ini diartikan sebagai proses mengumpulkan dan menganalisis kebutuhan dalam mengidentifikasi jenis pelatihan apa yang perlu dilakukan pada 30 anggota Persatuan Penyandang Disabilitas Indonesia (PPDI) Kabupaten Subang pada gambar 2 yang berada pada usia kerja baik yang sudah bekerja $(63,6$ persen) maupun yang belum bekerja (36,4 persen).

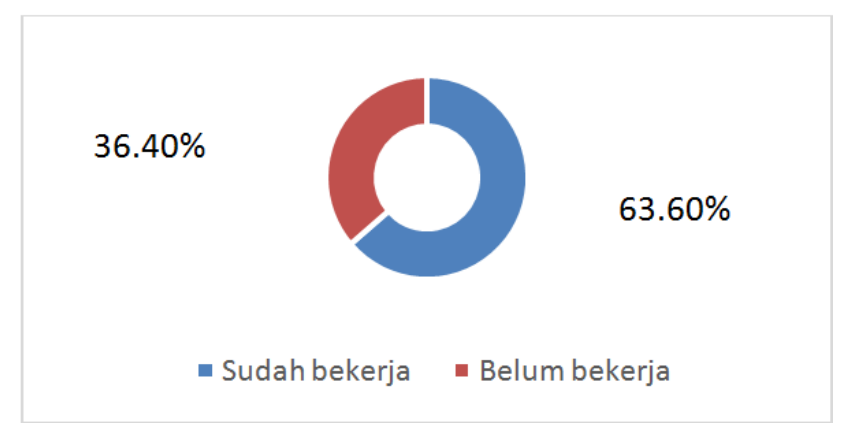

Gambar 2. Gambaran Umum Responden

Dalam gambar 3 mereka yang sudah bekerja terdiri dari tiga kategori yaitu $14 \%$ bekerja sebagai karyawan di usaha swasta, $86 \%$ berwirausaha dan belum ada responden yang bekerja di perusahaan/ organisasi pemerintah.Hal ini dideskripsikan pada gambar berikut:

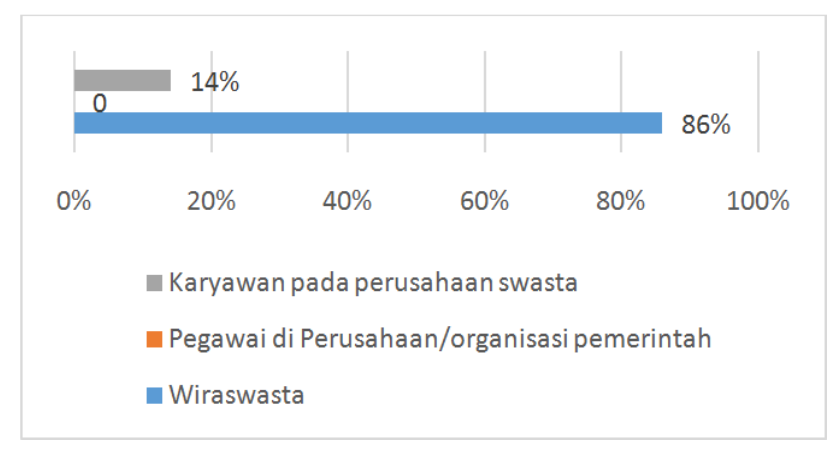

Gambar 3. Gambaran Responden yang sudah Bekerja 
Tidak adanya responden yang bekerja di lembaga pemerintahan dimungkinkan karena latar belakang pendidikannya yang sebagian besar lulusan SMP. Kondisi tersebut memberi kesempatan yang kecil bagi disabilitas untuk dapat bekerja di lembaga pemerintahan karena mereka harus bersaing dengan pencari kerja yang memiliki potensi lebih, sehingga mereka lebih banyak berwiraswasta. Padahal seharusnya mereka memiliki peluang yang sama, di mana menurut Undang-Undang nomor 8 tahun 2016 tentang penyandang disabilitas dijelaskan bahwa perusahaan milik pemerintah harus mempekerjakan disabilitas sebanyak 2 persen dari karyawannya dan perusahaan swasta sebanyak 1 persen.

Kemudian pada gambar 4 bagi responden yang belum bekerja, peneliti mengidentifikasi (1) bidang kemampuan responden dengan hasil sebagai berikut: responden yang memiliki keterampilan pada bidang pertanian sebesar $48 \%$, responden yang sudah memiliki keterampilan pada bidang pertukangan sebesar $48 \%$, responden yang sudah memiliki keterampilan pada bidang jasa sebesar 50\%, responden yang sudah memiliki keterampilan pada bidang wirausaha sebesar $65 \%$ dan responden yang sudah memiliki keterampilan pada bidang olahraga sebesar 53\%. Hal ini dideskripsikan dengan gambar berikut:

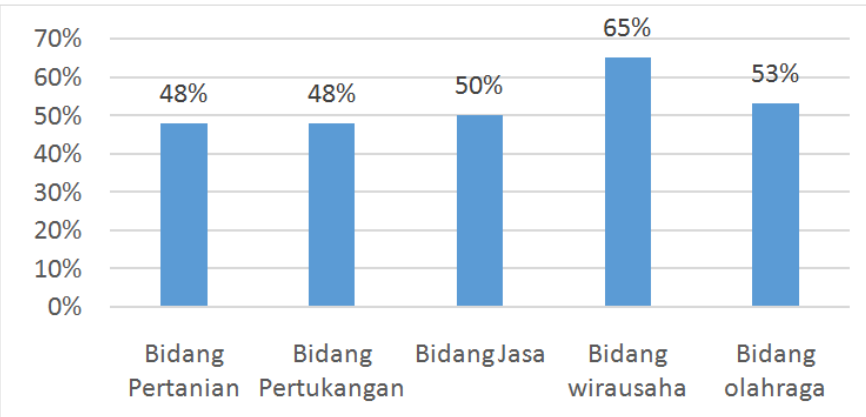

Gambar 4 Bidang Kemampuan Responden

Minat responden yang belum bekerja terdeskripsikan pada gambar berikut:

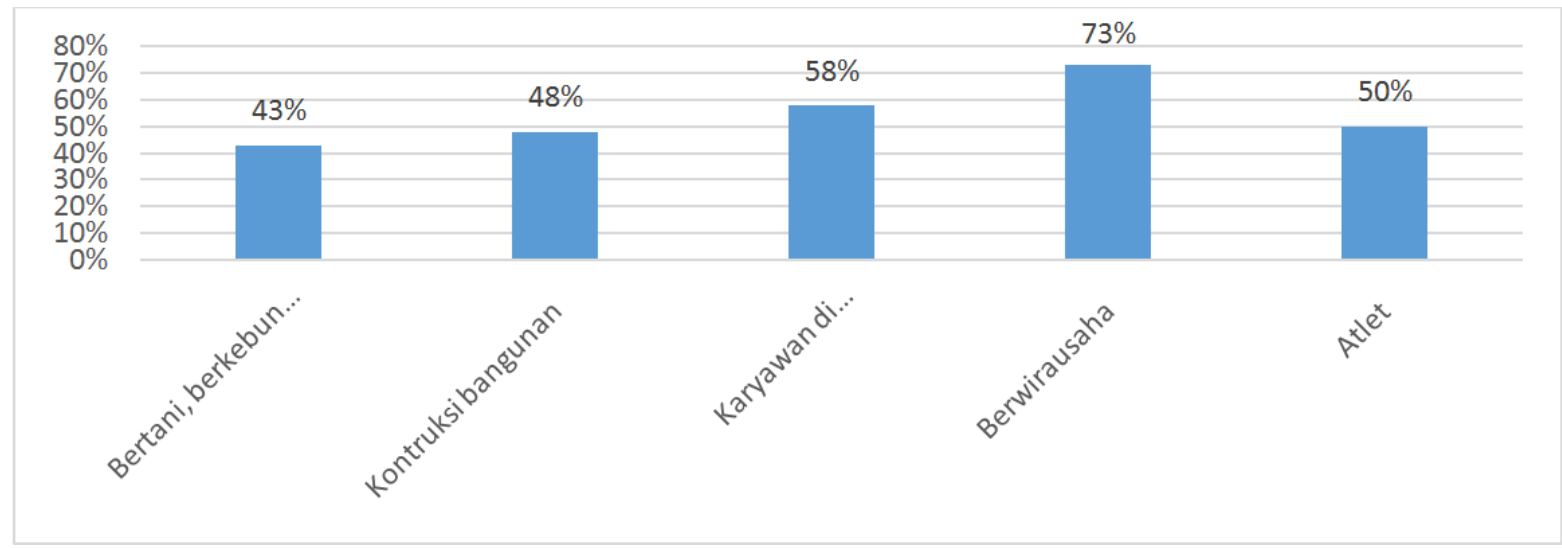

Gambar 5 Bidang Minat Responden

Berdasarkan gambar 5 responden yang memiliki minat pada bidang pertanian sebesar $43 \%$, responden yang memiliki minat pada bidang kontruksi bangunan sebesar $48 \%$, responden yang memiliki minat untuk menjadi karyawan pada sebuah lembaga/ perusahaan sebesar $58 \%$, responden yang memiliki minat pada bidang wirausaha
$73 \%$ dan responden yang memiliki minat pada bidang olahraga sebesar 50\%.Dari penemuan-penemuan di atas, dapat ditarik kesimpulan bahwa baik disabilitas yang sudah maupun yang belum bekerja cenderung untuk berwirausaha. Selain pertimbangan masalah fleksibilitas waktu, jam dan lokasi pekerjaan, menurut (Jones \& Paul, 2011) 
pemilihan wirausaha juga didasarkan pada pertimbangan akan kecenderungan dari terhindarnya diskriminasi di tempat kerja.

\section{Identifikasi Job Description}

Istilah wirausaha yang tepat digunakan untuk penyandang disabilitas adalah self-employer (wirausahawan) yang mempunyai pengertian orang-orang yang menjadi pendiri, pemilik dan manajer bisnis di bawah tanggung jawab mereka sendiri yang umumnya berupa kebanyakan perusahaan kecil (Caliendo et al., 2014). Masih terjadinya diskriminasi terhadap pencari kerja disabilitas diidentifikasi sebagai dorongan akan pentingnya bentuk pekerjaan wirausaha (self-employment) bagi penyandang disabilitas (Blanchflower, 2000). Selain itu, refklesi dan asumsi pada peluang wirausaha (self-employment) yang dapat mengakomodasi kecacatan mereka dalam fleksibilitas jam kerja dan alokasi kerja juga menjadi dorongan yang kuat. Sebuah studi melalui survey tahun 1989-2009 mengidentifikasi bahwa tingkat partisipasi wirausaha untuk penyandang disabilitas lebih tinggi daripada yang bukan penyandang disabilitas(Gouskova, 2012), hal tersebutseiring dengan meningkatya pendidikan dan pengalaman di hampir semua kelompok demografis dan jenis kelamin (Jones \& Paul, 2011).

Wirausahawan adalah orang yang merubah nilai sumber daya, tenaga kerja, bahan dan faktor produksi lainnya menjadi lebih besar daripada sebelumnya dan juga orang yang melakukan perubahan, inovasi dan cara-cara baru (Zimmerer \&Scarborough, 2008). Gambaran kerja mereka pada bidang usaha meliputi (Pambudi, 2017):

a. Perencanaan Usaha

Rencana usaha atau Stokes (1997) menyebutnya sebagai rencana bisnis pribadi berfungsi sebagai panduan untuk memfasilitasi penilaian terhadap jalur karier seseorang dan memungkinkan pemeriksaan diri terhadap nilai-nilai misalnya visi, sasaran, kekuatan, kelemahan, peluang, ancaman, dan kompetensi khas. Menurut Supriyanto (2009) secara garis besar isi suatu perencanaan bisnis dimulai dari ringkasan, statemen misi, faktor-faktor kunci, analisis pasar, produksi, manajemen dan analisis finansial. Perencanaan usaha ini dibuat sebaik mungkin dengan indikator yaitu sederhana, spesifik, realistik dan komplit (Supriyanto, 2009).

b. Pengorganisasian Usaha

Pengorganisasian didefinisikan sebagai proses kegiatan penyusunan struktur organisasi, mengelompokkan dan mengatur serta membagi tugas-tugas atau pekerjaan diantara anggota organisasi dan sesuai sesuai dengan sumber daya organisasi yang tersedia agar tujuan dapat dicapai dengan efisien (Robbins \& Coulter, 2010). Bentuk struktur organisasi akan berbeda-beda sesuai dengan jenis usahanya, di bawah ini merupakan salah satu bentuk struktur organisasi usaha (Agustina, 2018):

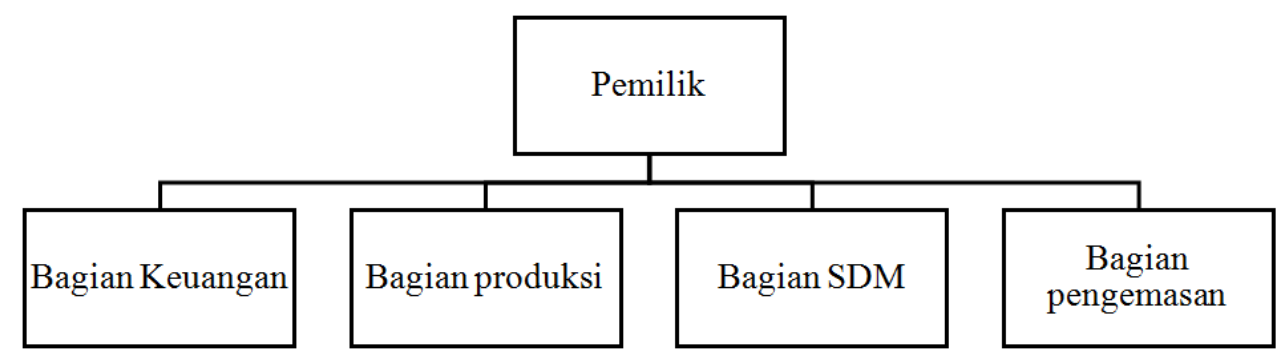

Gambar 6 Contoh Bagan Kepengurusan SebuahUsaha

Pada gambar 6 Pemilik sebagai atasan yang bertujuan untukmemimpindanmengatur seluk beluk perusahaan. Bagian keuangan bertugas mengatur aliran uang di dalam perusahaan. Bagian pengemasan bertugas mengemas barang-barang siap jual. Bagian produksi bertugas memproduksimembuat barang. Dan bagian SDM bertugas merekrut, melatih dan membimbing karyawan agar lebih kreatif dan produktif.

c. Pengarahan Usaha

Fungsi pengarahan diidentikan dengan arahan pemimpin dalam menugaskan karyawan untuk bergerak menuju tujuan 
(organisasi) yang telah ditetapkan. Maka dari itu, pelaksanaan fungsi pengarahan ini sangat ditentukan oleh kualitas, gaya dan kekuasaan manajer/pemilik usaha. Mutu perilaku seorang manajer yang baik meliputi dua yaitu managerial traits dan personal traits. Lebih jelasnya akan dibahasn pada pembahasan selanjutnya.

d. Pengawasan Usaha

Pengawasan usaha berarti fungsi manajemen yang memastikan bahwa aktifitas perusahaan sesuai dengan tujuan, visi dan misi perusahaan. Beberapa yang perlu diawasi dari sebuah usaha yang sedang dijalani adalah dari segi keuangan, sumber daya manusia, dan pemasarannya. Proses pengawasan ini sedikitnya terdiri dari 5 tahap yaitu (Agustina, 2019):

1) Penetapan standar pelaksanaan;

2) Penentuan pengukuran pelaksanaan kegiatan;

3) Pengukuran pelaksanaan kegiatan;

4) Pembandingan dengan standar dan penganalisaan penyimpangan-penyimpangan;

5) Pengambilan tindakan koreksi bila perlu.

Supaya pelaksanaannya efektif, sistem pengawasan harus benar, tepat waktu, biaya yang efektif, tepat-akurat dan dapat diterima oleh yang bersangkutan.

\section{Penetapan Kompetensi Ideal}

Menurut Mitchelmore \& Rowley (2010), seorang wirausaha setidaknya memiliki 6 kompetensi berikut mengidentifikasi dan mendefinisikan ceruk pasar yang layak, menentukan produk atau jasayang tepat, menghasilkan ide untuk mengembangkan usaha, mengenali lingkungan, mampu menangkap peluang dan mampu membuat strategi untuk menangkap peluang.

Pertama, mengidentifikasi ceruk pasar untuk melayani sejumlah pelanggan yang mencari manfaat sangat khusus (khas) dari produk dan jasa. Upaya mengidentifikasi ceruk pasar ini dilakukan untuk mencegah persaingan langsung dengan perusahaanperusahaan lebih besar yang memburu segmen yang lebih besar.

Kedua, penentuan produk atau jasa harus dilakukan dengan tepat. Pada umumnya apa yang dijual itu berupa produk atau jasa. Ada beberapa tips untuk menentukan produk atau jasa dalam memulai usaha yaitu mengikuti kebutuhan pasar, berdasarkan hobi atau passion sendiri, berdasarkan ketersediaan bahan baku atau sumber daya dan menentukan berdasarkan minat pasar.

Ketiga, menghasilkan ide untuk mengembangkan usaha. Pengembangan usaha dilakukan dalam menjaga eksistensi usaha, supaya usaha tersebut tidak bangkrut atau gagal. Ada beberapa tips dalam mengembangkan usaha yaitu tentukan tujuan dan penghasilan secara jelas (besaran dan waktu ketercapaiannya), membangun sistem yang kuat dan efektif supaya tidak mudah bangkrut, menyusun rencana strategi untuk mencapai target dan memberi pelayanan yang memuaskan untuk pelanggan.

Keempat, mengenali lingkungan. Lingkungan beserta orang-oang di dalamnya bisa menjadi inspirasi yang bagus untuk mencari atau mengembangkan ide usaha. Hal tersebut bisa dilakukan dengan bertemu, berinteraksi dan bergaul dengan sebanyalbanyak orang, mengamati problema lingkungan yang bisa jadi peluang usaha dan mempelajari pebisnis lain yang sudah dulu sukses.

Kelima, mampu menangkap peluang. Mereka yang berwirausaha mampu membuka usaha untuk dirinya sendiri dan bahkan menciptakan lapangan kerja untuk orang lain. Untuk bisa menangkap berbagai peluang (usaha) perlu dilakukan dengan berpikir positif dan kreatif yaitu memiliki etos kerja yang tinggi, percaya dan yakin bahwa usaha bisa berhasil, terampil dan mampu berkomunikasi, menerima gagasan baru dalam dunia bisnis yang sangat dinamis dan bersedia menerima saran dari orang lain (biasanya dari wirausaha yang telah sukses).

Keenam, mampu membuat strategi untuk memanfaatkan peluang. Seorang wirausaha perlu untuk memanfaatkan atau menangkap peluang yang tersedia, di tengah tantangan-tantangan usaha yang dihadapi. Strategi atau cara untuk memanfaatkan peluang tersebut adalah dengan melakukan riset pasar; membuat market plan misalnya terkait target pasar produk/ jasa, target 
pendapatan perbulan, biaya operasional dan sebagainya; mematuhi peraturan atau regulasi dari pemerintah setempat dan membuat strategi pemasaran yang tepat sasaran misalnya dengan pemanfaatan digital marketing.

Hal yang paling penting dari poin-poin di atas adalah "praktek". Seseorangtermasuk penyandang disabilitasharus berani mulai berwirausaha atas ide-ide dan analisis lingkungan pasar sehingga kemudian usaha bisa dijalankan dan berkembang secara bertahap dan berkelanjutan.

\section{Identifikasi Karakterisik}

Identifikasi karakteristik yaitu atribut atau ciri-ciri responden yang diperoleh karena kelahiran dan karena interaksi dengan lingkungan sosialnya. Identifikasi karakterisitik dalam penelitian ini dilihat dari jenis kedisabilitasan responden dan pendidikan terakhir yang ditempuh. Berdasarkan penelitian pada gambar 7 responden terdiri dari 14\% tunarungu, $73 \%$ tunadaksa, $5 \%$ tunanetra, $5 \%$ tunawicara dan $5 \%$ tidak teridentifikasi.

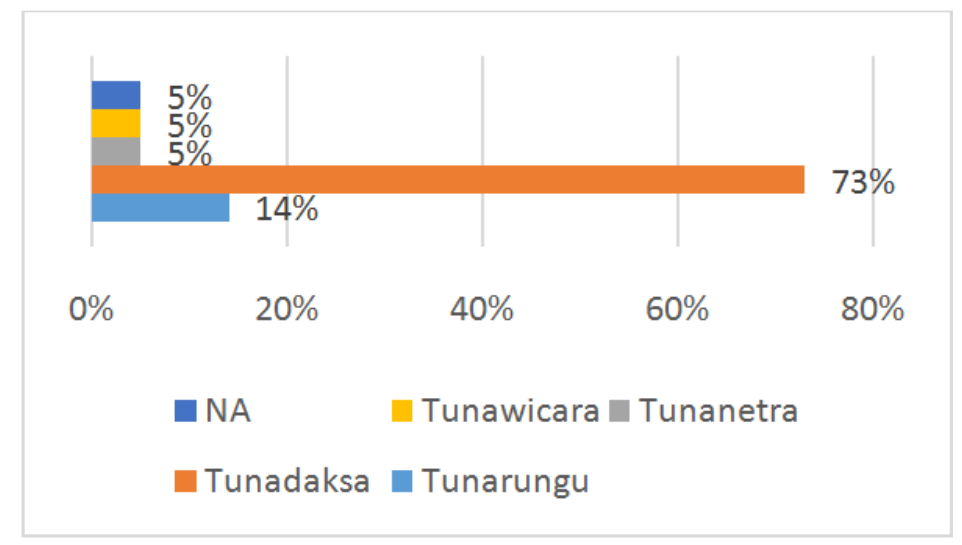

Gambar 7. Jenis Disabilitas Responden

Jika dilihat dari data gambar 7 dapat disimpulkan bahwa responden dengan kondisi kedisabilitasannya yang tunadaksa dan tunanetra, memiliki peluang untuk diberdayakan dengan mengarahkan kepada aktivitas pekerjaan yang tidak terlalu banyak menuntut gerak dan mobilisasi(Aprilia \& Johar, 2019). Demikian juga untuk responden tunarungu, banyak peluang pekerjaan yang dapat dilakukan hanya yang perlu disesuaikan adalah aksesibilitas bahasa dan komunikasi.

\section{Pengukuran kompetensi aktual}

Kemampuan bidang keahlian dan minat responden dalam penelitian terhadap wirausaha termasuk pada kategori paling tinggi. Menyadari hal tersebut, perlu dilakukan upaya yang bisa membantu mereka untuk membuka atau mengembangkan usahanya.Kondisinya, pada responden yang belum bekerja mereka kesulitan dalam menentukan bidang usaha yang akan dijalankan, takut untuk memulai usaha dan ketiadaan modal. Sedangkan pada responden yang sudah berwirausaha mereka masih terbatas melakukan usahanya secara konvensional, padahal jika dilakukan secara online juga dapat memberi keuntungan yang lebih dan pemasaran online seperti ini di zaman sekarang bisa dilakukan secara lebih fleksibel.Misalnya salah satu responden dari penyandang disabilitas tuna daksa yang juga merupakan pemilik usaha konveksi menyebutkan bahwa usaha konveksinya sampai saat ini masih dilakukan secara konvensional yaitu memasarkan dan menerima orderan secara manual dan masih terbatas dari daerah di sekitar rumah (Mimin, 2019).

\section{Penetapan kesenjangan kompetensi}

Menjadi pengusaha di era digital yang menawarkan berbagai kemudahan merupakan sebuah kesempatan sekaligus tantangan. Saat ini misalnya transaksi jualbeli barang/ jasa bisa dilakukan tanpa harus memiliki tempat jualan secara fisik dalam bentuk rumah, toko atau ruko yaitu melalui aplikasi digital dan dengan pemanfaaatan teknologi internet. Wawanacara dengan salah satu responden yang belum bekerja di 
mana dia termasuk penyandang disabilitas tunarungu menyebutkan keinginannya untuk bisa membuka usaha online di tengah keterbatasan yang dimilikinya untuk bisa mandiri secara finansial. Selain itu, ada juga wawancara dengan salah satu responden tunadaksa yang juga pemilik usaha konveksi bahwa keterbatasan yang dihadapi dalam usahanya adalah sampai saat ini kegiatan usahanya baru beroperasional secara manual, keinginannya usahanya juga bisa dikembangkan secara online.

\section{Rekomendasi}

Pelatihan ini berupaya untuk mengakomodir seluruh peserta baik yang sudah bekerja maupun belum bekerja. Dengan mempertimbangkan hasil analisis yang telah dilakukan dalam beberapa tahap sebelumnya, seminar dan workshop kewirausahaan ini diarahkan pada digital marketing. Pelatihan digital marketing diberikan kepada penyandang disabilitas supaya potensi besar perkembangan IPTEK yang bisa jadi sumber penghasilan dapat dirasakan juga oleh penyandang disabilitas (yang belum maupun sudah bekerja). Di sisi lain, digital marketingdalam wirausaha sangat esensial karena teknologi informasi dan komunikasi yang berkembang saat ini semakin memudahkan dalam menarik pelanggan untuk mulai menarik pembeli dan bahkan mengembangkan jangkauan pasar sebuah usaha yang lebih luas (Bisnis UKM, 2019). Maka dari itu pelatihan ini diarahkan tentang digital marketing.

\section{Tindaklanjut}

Ada tiga tahapan yang dilakukan dalam kegiatan pelatihan pada penyandang disabilitas yaitu sebagai berikut:

Tabel 1 Upaya Tindaklanjut

\begin{tabular}{cll}
\hline No & \multicolumn{1}{c}{ Materi } & \multicolumn{1}{c}{ Sasaran dan Tujuan } \\
\hline 1 & $\begin{array}{l}\text { Membangun karakter (character } \\
\text { building) para penyandang disabilitas }\end{array}$ & $\begin{array}{l}\text { Para penyandang disabilitas dapat mengenali } \\
\text { sebaik-baik kelebihan, kekurangan dan } \\
\text { potensi yang dimiliki untuk kemudian bias } \\
\text { dikembangkan. }\end{array}$ \\
\hline 2 & Menumbuhkan jiwa kewirausahaan & $\begin{array}{l}\text { Para penyandang disabilitas menyadari } \\
\text { pentingnya hidup mandiri secara ekonomi dan }\end{array}$ \\
& (self employment) pada penyandang & memulai untuk bekerja dan/ atau berwirausaha \\
\hline 3 & Disabilitas & Pembekalan keterampilandigital marketing \\
& untuk penyandang disabilitas & $\begin{array}{l}\text { Para penyandang disabilitas dibekali dengan } \\
\text { sebuah keterampilan pemasaran digital dengan } \\
\text { praktek langsung }\end{array}$ \\
\hline
\end{tabular}

\section{KESIMPULAN}

Kemandirian penyandang disabilitas bisa diupayakan dengan pengembangan karir di antaranya melalui kegiatan seminar dan workshop pembekalan soft skill dan hard skill yang dibutuhkan. Kegiatan ini diharapakan bisa mengakomodasi semua peserta baik yang baru merintis usaha maupun mengembangkannya.

\section{DAFTAR RUJUKAN}

Agustina, D. (2019). Fungsi Manajemen (POAC) dalam UMKM. Diakses dari https://www.academia.edu/9531603/ Fungsi_Manajemen_POAC_dalam_UMKM pada 12 Agustus 2019.

Aprilia, I. D. (2009). Pengembangan Kemandirian Remaja Tunarungu. Jurnal Asesmen dan Intervensi Anak Berkebutuhan Khusus, 8 (2), 117-127.

Aprilia, I. D \& Johar, P. (2019). Pemberdayaan Organisasi Kemasyarakatan melalui Usaha Ekonomi bagi Penyandang Disabilitas di Kabupaten Subang.Jakarta: Kementerian Riset, Teknomogi dan Pendidikan Tinggi Republik Indonesia.

Baker-Ericzen, M. J., Mueggenborg, M. G. \& Shea, M. M. (2009). Impact of Trainings on Child Care Providers'Attitudes and Perceived Competence Toward Inclusion: What Factors Are Associated with Change?.Topics inEarly Childhood Special Education 28 (4), 196-208.

Bisnis UKM. (2019). Strategi Pemasaran Paling Ampuh di Era Digital. Diakses dari https://bisnisukm.com/ strategi-pemasaran-paling-ampuh-di-era-digital.html pada 13 Agustus 2019. 
Blanchflower, D. (2000). Self-employment in OECD countries. Labour Economics 7. 471-505.

Caliendo, M., Fossen, F., \& Kritikos, A. S. (2014). Personality Characteristics and the Decisions to Become and Stay Self-Employed. Small Business Economics, 42 (4), 787-814.

Gouskova, E. (2012). Self-employment among people with disabilities: Evidence from the current population survey. Diakses dari SSRN 2175687.

International Labour Organization. (2013). Mewujudkan Peluang Kerja yang Setara bagi Para Penyandang Disabilitas Melalui Perundang-Undangan: Petunjuk Pelaksanaan/Kantor Perburuhan Internasional. Jakarta: International Labour Organization

Jones, M. K. \& Paul, L. L. (2011) Disability and self-employment: evidence for the UK. Applied Economics, 43 (27), 4161-4178.

Kementerian Sosial Republik Indonesia. (2012). Pedoman Analisa Kebutuhan Diklat. Jakarta: Kementerian Sosial Republik Indonesia.

Kerka, S. (2002). Learning Disabilities and Carier Development. Columbus: ERIC Clearinghouse on Adult Career and Vocational Education, Office of Educational Research and Improvement, Departement of Education.

Kerlinger, F. M. (1964). Foundation of Bihavioral Research. New York: Holt, Rinehart \& Winstron.

Kustiani, R. (2019). Laninka Siamiyono, Beauty Vlogger Gagas 2.000 Lipstik Tuk Difabel. [Online].Diakses dari https://difabel.tempo.co/read/1234904/laninka-siamiyono-beauty-vlogger-gagas-2-000-lipstik-tukdifabel pada 15 Agustus 2019.

Mitchelmore, S., \& Rowley, J. (2010). Entrepreneurial Competencies: A Literature Review and Development Agenda. International Journal of Entrepreneurial Behavior \& Research, 16 (2), 92-111.

Permana, J \&Liah, S. S. (2018). Management of Internship for Special Schools. Presented in IASTEM International Conference Kuala Lumpur, Malaysia 18-12-2018. [Online].Diakses dari https://worldresearchlibrary.org/ proceeding.php?pid=2413 pada 10 Agustus 2019.

Permana, J. Eka, P., Imas, D. A \&Liah, S. S. 2019. School Coperation Management in Implement of Life Skill Education for Disability Student. Telah Dipresentasikan di International Conference on Research of Educational Administration and Management 2019 pada 17 Juli 2019.

Myklebust, J. O\& Finn Ove, B. (2005). Economic independence for adolescents with special educational needs. European Journal of Special Needs Education, 20 (3), 271-286.

Natsir, M. (1999). Metode Penelitian. Jakarta: Penerbit Galia Indonesia.

Novalina \& Rusiadi. (2018). Confirmatory Factor Analysis terhadap Kemandirian Ekonomi Wanita Pesisir Berbasis Kesejahteraan Keluarga Nelayan Desa Pahlawan Kecamatan Tanjung Tiram. Jurnal Kajian Ekonmi Dan Kebijakan Publik, 3 (1), 65-74.

Pambudi, Z. R. (2017). Pengelolaan Wirausaha Oleh Difabel Daksa (Studi pada Usaha Sablon Munajat di Galeri Balai Rehabilitasi Terpadu Penyandang Disabilitas Pundong Yogyakarta). [Skripsi]. Yogyakarta: UIN Sunan Kali Jaga Yogyakarta.

Robbins, S \& Coulter, M. (2010). Manajemen Edisi Kesepuluh. Jakarta: penerbit Erlangga.

Schriner, K. (2001). A disability studies perspective on employment issues and policies for disabled people: an international view, in: G. Albrecht, K. Seelman \& M. Bury (Eds) Handbook of disability studies (London, Sage).

Stokes, S. L. (1997). Developing a Personal Business Plan. Information Systems Management, 14(2), 70-73.

Supriyanto. (2009). Business Plan sebagai Langkah Awal Memulai Usaha. Jurnal Ekonomi \& Pendidikan, 6 (1),73-83.

Tehrani, M. H. (2004). Kemandirian Ekonomi Solusi Kesejahteraan. Bogor: Governance Brief, http://www.cifor.cgiar.org

Zimmerer, T. W \& Scarborough, N. M. (2008). Kewirausahaan dan Manajemen Usaha Kecil. Salemba empat.

Triyudha, A. (2018). Pelibatan Disabilitas di Dunia Kerja Minim. Diakses dari http://www.harnas.co/2018/12/04/ pelibatan-disabilitas-di-dunia-kerja-minim pada 15 Agustus 2019.

Undang-Undang no 8 Tahun 2016 tentang Penyandang Disabilitas.

Wasita, A. (2019). Pemerintah dorong penyandang disabilitas mandiri secara ekonomi. [Online]. Diakses dari https://jateng.antaranews.com/berita/233237/pemerintah-dorong-penyandang-disabilitas-mandiri-secaraekonomi pada 30 Agustus 2019. 